\title{
PELATIHAN DIVERSIFIKASI PEMANFAATAN IKAN BANDENG LAKI (Elops hawaiensis) MENJADI PRODUK BERGIZI DAN BERNILAI EKONOMIS DI KELURAHAN KARANG REJO KOTA TARAKAN
}

\section{Diversification Of Elops Hawaiensis Utilization Training Become a Nutritious and Economical value Product In Kelurahan Karang Rejo Kota Tarakan}

\author{
Tri Paus Hasiholan Hutapea ${ }^{1}$ Imra $^{2}$, Dhimas Wiharyanto ${ }^{3}$ \\ ${ }^{1}$ Jurusan Teknologi Hasil Perikanan, Fakultas Perikanan dan Ilmu Kelautan, Universitas Borneo Tarakan \\ ${ }^{2}$ Jurusan Manajemen Sumberdaya Perairan, Fakultas Perikanan dan Ilmu Kelautan, Universitas Borneo Tarakan \\ Jl. Amal Lama No. 1. Pos No. 77122 - Tarakan 20221
}

Email : hutapea2606@gmail.com

\begin{abstract}
ABSTRAK
Ikan bandeng laki adalah hasil samping dari panen tambak udang. Ikan ini memiliki nilai jual yang sangat rendah, sehingga sering dibuang oleh masyarakat. Salah satu cara yang dilakukan untuk meningkatkan nilai gizi dan nilai jual dari ikan bandeng laki adalah mengolah ikan tersebut menjadi produk yang beragam dan menarik untuk dikonsumsi. Cara ini disebut Diversifikasi Produk Perikanan. Tentunya masyarakat masih memiliki pengetahuan yang minim mengenai Diversifikasi Produk Perikanan, sehingga dibutuhkan pelatihan mengenai Diversifikasi produk perikanan. Melalui Program Kemitraan Masyarakat akan dilakukan Pelatihan Diversifikasi Produk Hasil Tangkapan Ikan bagi Masyarakat Karang Rejo Kota Tarakan Provinsi Kalimantan Utara. Diharapkan melalui program ini masyarakat mampu mengolah hasil tangkapan dengan olahan yang beragam dan menarik untuk dikonsumsi.
\end{abstract}

Kata Kunci: Bandeng Laki, Karang Rejo, Diversifikasi

\section{ABSTRACT}

Elops hawaiensis is a by-product of harvesting shrimp farms. This fish has a very low selling value, so it is often disposed of by the community. One way that is done to improve nutritional value and the selling value of male milkfish is to process these fish into diverse and interesting products for consumption. This method is called Diversification of Fishery Products. Of course the community still has minimal knowledge regarding Diversification of Fisheries Products, so training is needed on Diversification of fishery products. Through the Community Partnership Program, a Diversification of Fishing Products for the Karang Rejo Community of Tarakan City, North Kalimantan Province will be held. It is expected that through this program the community will be able to process various and interesting catches for consumption.

Keywords: Elops hawaiensis, Karang Rejo, Diversification

\section{PENDAHULUAN}

Kota Tarakan memiliki potensi sumberdaya perikanan yang cukup beragam. Diantara potensi tersebut, berupa hasil budidaya udang yang dilakukan di sekitar pulau Tarakan. Kondisi sekitar yang berupa kawasan delta dari sungai - sungai besar dari Pulau Kalimantan dengan kondisi air yang bersifat payau ditumbuhi oleh dengan ekosistem mangrove sehingga sangat layak untuk kegiatan budidaya udang.

Pengoperasian kegiatan budidaya udang yang dilakukan oleh masyarakat di sekitar Kota Tarakan pada umumnya dilakukan secara tradisional. Adapun ciri tambak ini memiliki ukuran lahan yang relative luas dan sistem dalam pemeliharaannya sangat minim menggunakan teknologi serta mengandalkan pakan alami dari dalam tambak dan perairan sekitarnya. 
Tingkat produksi tambak udang di sekitar Kota Tarakan masih rendah dimana berkisar rata - rata $7 \mathrm{Kg}$ per Ha. Hasil panen yang didapatkan bervariasi bukan hanya udang tapi terdapat kepiting, udang liar lain dan berbagai jenis ikan. Dalam pemanfaatannya biasaya hanya ikan tertentu saja yang mimiliki nilai ekonomis tinggi yang diambil dan dijual serta dimanfaatkan oleh petani tambak. Ikan jenis lainnya yang dinilai kurang ekonomis akan dibuang. Jenis ikan yang sering kali dibiarkan dan terbuang tanpa pemanfaatan adalah ikan bandeng laki (Elops hawaiensis).

Ikan bandeng laki ini sering kali didapati tidak dimanfaatkan karena dalam tubuhnya terdapat banyak duri sehingga menyulitkan dalam konsumsinya. Sebenarnya ikan ini memiliki potensi yang sangat tinggi dan dapat memberikan hasil tambahan pendapatan yang tinggi jika dimanfaatkan menjadi olahan/makanan hasil perikanan yang memiliki kandungan nilai gizi tinggi dan bernilai ekonomis. Usaha penangkapan dan pengolahan ikan merupakan hulu dan hilir dalam agrobisnis perikanan (Fatih, 2010).

Kelurahan Karang Rejo bagian pantai mayoritas memiliki pekerjaan bergerak dalam kegiatan perikanan diantaranya petani udang, penjaga tambak dan nelayan. Tingkat perekonomian untuk rumah tangga dengan pekerjaan penjaga tambak dan nelayan kecil relatif rendah, sehingga diperlukan alternatif sumber pendapatan tambahan dengan mengoptimalkan peran ibu rumah tangganya. Pemanfaatan hasil panen tambak seperti ikan bandeng laki (Elops hawaiensis) yang tidak termanfaatkan menjadi peluang yang baik untuk dimanfaatkan sebagai upaya sumber alternatif pendapatan tambahan.
Pemanfaatan ikan bandeng laki menjadi berbagai bahan makanan olahan hasil perikanan memiliki nilai ekonomi dan nilai gizi yang tinggi dengan rasa yang khas. Produk makanan ini diharapkan menjadi salah satu pendukung dalam peningkatan pendapatan dan kebutuhan makanan yang bergizi untuk rumah tangga nelayan dan penjaga tambak di kelurahan Karang Rejo bagian pantai Kota Tarakan. Kedepan nantinya, produk makanan olahan berbahan dasar ikan buangan ini dapat menjadi oleholeh khas Kota Tarakan yang menarik dan bernilai ekonomis. Dengan demikian jika kondisi telah berjalan dengan baik maka akan berdampak kepada peningkatan perekonomian masyarakat di sekitar kawasan ini.

\section{METODE}

\section{Teknik Pelaksanaan Kegiatan}

Pelaksanaan kegiatan dilaksanakan dengan teknik ceramah, diskusi yang disertai praktek dan pendampingan langsung selama proses pelatihan berlangsung. Materi pelatihan dipilih berkaitan dengan potensi dan pemanfaatan hasil perikanan dalam upaya mendukung perekonomian masyarakat, yang dilanjutkan dengan tutorial, praktek dan pendampingan pembuatan makanan olahan berbahan dasar ikan yang dibuang.

\section{Jenis dan Pemanfaatan Hasil Perikanan}

Dalam kegiatan ini bertujuan untuk memberikan pengetahuan dan peningkatan keterampilan kepada masyarakat di Kelurahan Karang Rejo bagian pantai khususnya ibu rumah tangga dalam bentuk seminar pengoptimalan pemanfaatan hasil perikanan yang dibuang serta praktek pembuatan makanan yang berbahan dasar ikan dalam bentuk pelatihan. 
Dalam kegiatan ini, ikan yang berasal dari hasil panen yang dibuang akan diolah menjadi beberapa jenis makanan yang harapan kedepannya dapat dijual pada kios khusus buah tangan Kota Tarakan atau tempat pemasaran lainnya oleh masyarakat dan bahkan menjadi oleh-oleh khas Kota Tarakan. Berikut ini beberapa jenis makanan yang merupakan produk olahan ikan.

1. Pempek Palembang

2. Bakso ikan

3. Otak-otak ikan

\section{Prosedur Pembuatan Makanan}

\section{a. Pempek Palembang}

Bahan-bahan yang dibutuhkan untuk pempek seperti berikut :

1. Menyediakan air bersuhu tinggi dan tambahkan garam, penyedap rasa, bawang putih, tepung terigu, gula pasir. Aduk hingga merata dan adonan jadi kental, kemudian dinginkan.

2. Jika sudah dingin tambahkan telur dan daging ikan bandeng laki, uleni hingga adonan terasa lembut dan halus.

3. Kemudian tambahkan tepung sagu dan aduk rata, uleni secara perlahan saja dan jangan biarkan tepung sagunya tercampur rata. Jika terasa lengket dan susah dibentuk maka tambahkan sedikit tepung sagu lagi agar adonan mudah di bentuk.

4. Panaskan air untuk merebus, lalu ambil adonan empek-empek, bentuk menjadi bulat pipih dan isi telur, kemudian dibentuk.

5. Masukan adonan tersebut ke dalam air yang sudah mendidih, rebus hingga mengapung dan matang. Kemudian angkat dan tiriskan.

\section{b. Bakso Ikan}

Cara membuat bakso ikan yang mudah dan praktis sebagai berikut:

1. Langkah pertama masukkan daging ikan bandeng laki ke dalam blender bersama dengan putih telur, bawang putih, garam dapur beryodium, gula pasir dan es serut sedikit saja. Haluskan semua bahan tersebut sampai benar-benar halus.

2. Siapkan satu wadah dan tuang hasil blenderan ikan diatas.

3. Tuang tepung sagu atau tepung tapiokanya sambil diaduk-aduk dan diuleni searah jarum jam dan sedikit digilas seperti mencuci baju sampai semua bahan tercampur rata (kurang lebih selama 5 menit).

4. Tepung sagu atau tapioka bisa ditambahkan sedikit saja apabila dirasa masih terlalu lembek.

5. Siapkan panci dan rebus air bersih secukupnya sampai mendidih kemudian matikan apinya.

6. Bentuk adonan bakso diatas di genggaman tangan dan tekan sampai membentuk bulatan bakso.

7. Ambil adonan bakso diatas dengan sendok makan dan masukkan ke dalam air panas di dalam panci. Ulangi sampai adonan pentl bakso ikannya habis.

8. Rebus kembali bakso diatas dengan api sedang kecil sampai pentol bakso mengambang dan matang.

9. Setelah matang segera angkat dari panci, tiriskan dang dinginkan.

\section{c. Otak - Otak Ikan}

Berikut ini cara pembuatan otak - otak ikan.

1. Campur ikan giling, sagu, telur, garam, santan, gula, air es, putih telur dan bumbu halus jadi satu.

2. Siapkan daun pisang yg sudah dilayur. 
3. Isi daun pisang dengan bahan ikan.

Setelah selesai kuku / panggang dibara api bisa juga di teflon atau pemanggang lainnya.

\section{HASIL DAN PEMBAHASAN \\ Pelaksanaan Kegiatan}

Kegiatan Pelatihan Diversifikasi Pemanfaatan Ikan Bandeng Laki (Elops hawaiensis) Hasil Samping Panen Tambak Udang Yang Dibuang Menjadi Panganan Yang Bergizi dan Bernilai Ekonomis Di Desa Karang Rejo Kota Tarakan telah berlangsung pada tanggal 18 November 2017. Kegiatan berlangsung dengan baik dan lancar. Pelatihan ini dihadiri oleh 30 orang termasuk panitia dan peserta. Pelatihan dilakukan dirumah Bapak Donur daerah Karang Rejo.

Kegiatan demi kegiatan diikuti oleh peserta dengan baik. Pembukaan acara diawali oleh ketua panitia, dilanjutkan oleh sambutan-sambutan. Pada kegiatan ini dihadari oleh Kepala Seksi Pemberdayaan Kelurahan Karang Rejo Kota Tarakan, dalam sambutannya beliau sangat mengapresiasi kegiatan yang positif ini. Pihak kelurahan sangat berharap setelah kegiatan ini selesai, para peserta / Ibu-ibu yang berada di Kelurahan Karang Rejo memiliki minat untuk membuat Home Industri yang menghasilkan produk olahan hasil samping panen tambak udang untuk dapat dijual dan tentunya akan meningkatkan kesejahteraan masyarakat.

Pada saat praktik diversifikasi, para peserta antusias untuk mendengarkan dan mengikutinya. Peserta membantu pelatih untuk menyiapkan bahan-bahan yang diperlukan. Semangat dan antusias dari peserta menunjukkan niat belajar yang tinggi dari peserta untuk mengetahui cara pengolahan hasil samping panen tambak udang berupa ikan bandeng laki menjadi olahan yang bergizi dan memiliki nilai jual yang tinggi.

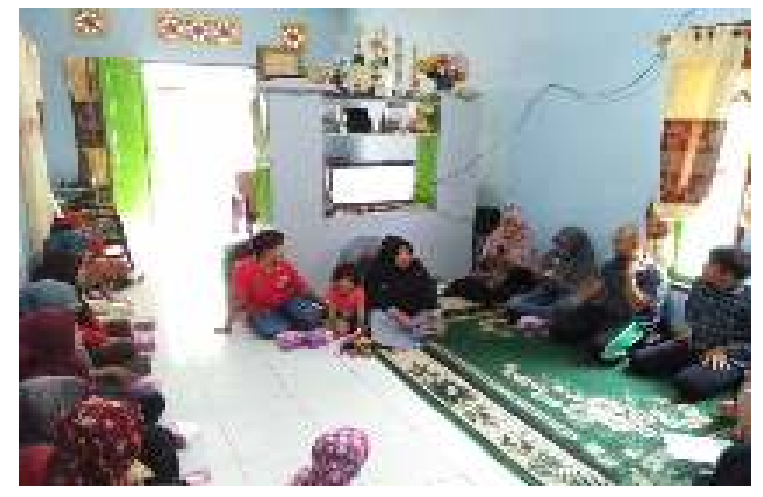

\section{Gambar 1. Suasana Pembukaan Acara}

Minat masyarakat terkhususnya ibu-ibu terhadap pelatihan pengolahan ikan didaerah karang rejo sangat tinggi, hal ini menunjukkan pelatihan seperti ini sangat dibutuhkan oleh masyarakat. Salah satu peserta dalam menyampaikan pesan dan kesan, mengatakan hal positif tentang kegiatan ini dan sangat mengapresiasi kegiatan ini. Dia sangat berharap kegiatan ini terus berlangsung secara bertahap.

\section{Diversifikasi Pemanfaatan Ikan Bandeng Laki}

Diversifikasi hasil perikanan merupakan proses penambahan nilai ekonomi hasil perikanan dengan pengolahan yang beragam (Vatria, 2010). Hasil samping dari panen tambak udang berupa ikan bandeng laki memiliki nilai ekonomis yang rendah dan masyarakat nelayan sudah terbiasa membuang hasil samping tersebut.

Pengetahuan masyarakat mengenai olahan hasil samping berupa bandeng laki masih sangat minim sehingga diperlukan diversifikasi pengolahan ikan bandeng laki sebagai makanan yang bernilai ekonomi yang tinggi dan dapat laku dipasaran. Pada kegiatan ini dilakukan pelatihan pembuatan Pempek Palembang, Bakso ikan, Kerupuk ikan dan Otak-otak ikan. Pempek Palembang merupakan makanan khas 
Indonesia. Makanan ini diminati masyarakat karena faktor kebudayaan, social dan psikologis (Ani, 2001).

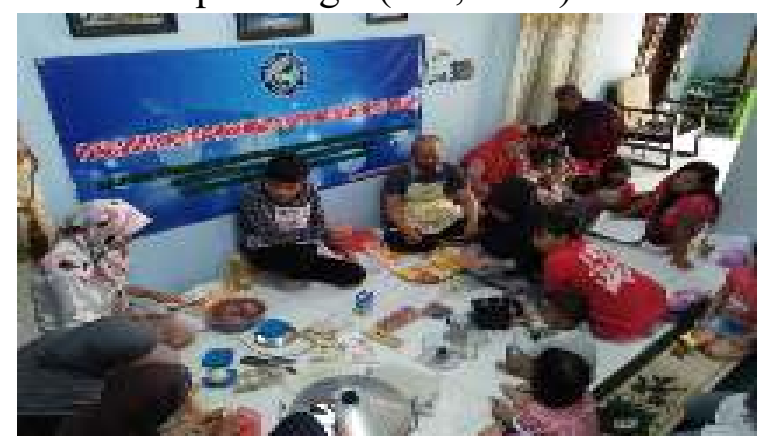

Gambar 2. Suasana Pada Saat Praktik Pengolahan

Dalam pengolahan ikan bandeng laki tidak hanya mengutamakan nilai gizi, namun juga diperhatikan dari bentuk dan tekstur. Nilai gizi dari diversifikasi pengolahan bandeng laki akan didukung dengan penambahan bumbu-bumbu yang disediakan, sedangkan untuk bentuk dan tekstur dapat dimaksimalkan melalui prosedur pembuatan yang benar.. Memperhatikan bentuk dan tekstur bertujuan untuk menghasilkan olahan yang baik dan laku dipasaran. Pasar akan mencari olahan yang bergizi dan memiliki bentuk dan tekstur yang baik. Dalam pelatihan ini telah disiapkan prosedur pembuatan olahan makanan. Hasil yang didapatkan menunjukkan bentuk dan tekstur hasil olahan yang sangat baik.

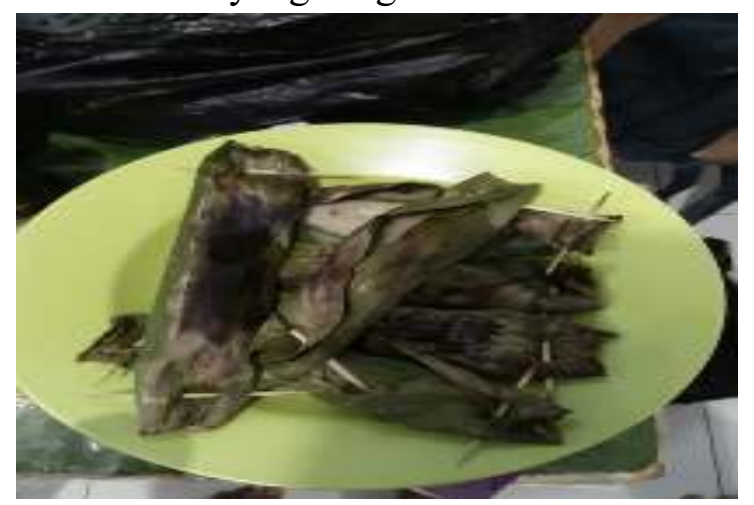

Gambar 3. Hasil Olahan

4. PENUTUP

Kegiatan Pelatihan Diversifikasi Pemanfaatan Ikan Bandeng Laki (Elops Hawaiensis) Hasil Panen Tambak Udang Yang Dibuang Menjadi Panganan Yang Bergizi Dan Bernilai Ekonomis sebagai bentuk pengabdian kepada masyarakat oleh universitas borneo. Kegiatan dilakukan dikelurahan karang rejo kota Tarakan. Kegiatan pengabdian ini mendapatkan respon yang positif dari masyarakat dan pihak kelurahan. Hasil kegiatan memberikan pengetahuan baru bagi masyarakat untuk mengolah hasil samping panen tambak udang berupa ikan bandeng laki sehingga bernilai ekonomis dan memliki gizi yang baik.

\section{DAFTAR RUJUKAN}

Ani, L. (2001). Preferensi Konsumen Terhadap Olahan Perikanan (Pempek). Skripsi tidak dipublikasikan. Bogor: Program Studi Sosial Ekonomi Perikanan IPB.

Fatih, C. (2010). Strategi Pengembangan Agroindustri Perikanan Laut Di Kabupaten Tuban. JSEP (Journal of Social and Agricultural Economics), [S.1.], v. 4, n. 3, p. 77-88

Pemerintah Kota Tarakan. 2001. Evaluasi dan Perencanaan Sumberdaya Pesisir dan Laut Kota Tarakan. Fakultas Perikanan dan Ilmu Kelautan. Universitas Mulawarman. Samarinda.

Vatria, B., (2010). Pengolahan Ikan Bandeng (Chanos chanos) Tanpa Duri. Jurnal Ilmu Pengetahuan dan Rekayasa, (1), 18-24. 